\title{
慢性中耳炎手術症例に抢ける迷路㾇孔の検討
}

\author{
前田 学・斉藤 龍介・中川 文夫・宇野 芳史 \\ 園部 紀子・金谷 眞・渡辺 周一*
}

\section{Labyrinthine Fistula during Chronic Ear Surgery}

\author{
Manabu Maeta, Ryusuke Saito, Fumio Nakagawa, Yoshifumi Uno, \\ Noriko Sonobe and Makoto Kanadani \\ (Okayama Saiseikai General Hospital) \\ Shuichi Watanabe \\ (Okayama University Medical School)
}

\begin{abstract}
Twenty cases of labyrinthine fistula have been reviewed. From 1988 to 1993, surgery was performed on 384 ears with chronic otitis media, and 20 of these cases had a labyrinthine fistula (incidence 5.2\%). All twenty cases had a lateral semicircular canal fistula and one case had an additional superior semicircular canal fistula. There was no relationship between the size of the labyrinthine fistula and the incidence of vertigo or fistula symptoms. Also there was no relationship between the size of the labyrinthine fistula and preoperative bone conduction thresholds. All twenty cases were characterized by chronic otitis media with cholesteatoma, and the matrix of the cholesteatoma was completely removed in all patients with the exception one case where the cholesteatoma was enormous. Preoperative bone conduction hearing was preserved after removal of the cholesteatoma matrix in all cases except the latter.

These results suggest that lesions over the lateral semicircular canal fistula should be completely removed, at best with care, when they are discovered during chronic ear surgery. This policy rarely causes lateral semicircular canal fistula bone conduction hearing to become worse.
\end{abstract}

Key words : labyrinthine fistula, ear surgery, chronic otitis media, cholesteatoma, bone conduction hearing

\section{はじめに}

迷路瘦孔は慢性中耳炎の合併症の 1 つであり, 特に真 珠腫性中耳炎では手術例の約 $10 \%$ 前後に認められると報 告され，真珠腫症例の手術に際して絶えず念頭において おかねばならない。近年, 画像診断の著しい進歩により 瘦孔の術前診断はそれほど困難ではなくなり，手術に際 してあらかじめ瘦孔の部位，大きさを予測することが可 能になってきた. しかし, その瘦孔部病変の処理には絶 えず術後内耳障害の危険がつきまとい，どのようにこの
病変を処理するかについては尚議論が多く, 確立された 方法はない. 今回, われわれは慢性中耳炎手術時, 迷路 瘦孔を認めた症例について臨床的観察を行い, 発生頻度, 症状, 手術所見, 処理法と予後について検討したので報 告する.

\section{対象・患者背景}

1988年 8 月から1993年 7 月までの 5 年間に岡山済生会 総合病院耳鼻咽喉科で慢性中耳炎の手術を施行した 384 
耳を対象とした。

このなかで手術中に迷路㾇孔が認められたものは 20 耳 で全手術耳中 $5.2 \%$ 頻度であった. 20 耳寸べてが真珠 腫性中耳炎で，真珠腫性中耳炎中の迷路㾞孔の頻度は $13.2 \%$ で，上鼓室型真珠腫に迷路瘦孔の合併が最も多く 認められた(表 1 ). 年齢は14歳から76歳(平均45.3歳), 男女各10耳であった。また，初回手術は17耳，再手術は 3 耳で，いずれも瘉着型真珠腫の遺残性再発例であった。 な拉，20耳すべての手術は全身麻醉下に施行された.

術前聴力は, 気導聴力が 4 分法平均聴力で $45.3 \pm 15.7$ $\mathrm{dB}, 4 \mathrm{kHz}$ が $52.0 \pm 20.2 \mathrm{~dB}$. 骨導聴力は， 4 分法平均 聴力で $15.3 \pm 12.0 \mathrm{~dB}, 4 \mathrm{kHz}$ が $26.5 \pm 18.6 \mathrm{~dB}$. 気骨 導差は $30.1 \pm 12.2 \mathrm{~dB}$ であった(表 2 ).

自覚症状としては，耳漏が 19 耳 $(95 \%)$, 難聴が 18 耳 (90\%) と高率に認められたが，局所処置や気流などの圧

表 1 迷路瘦孔と真珠腫病型

\begin{tabular}{lr}
\hline \hline 上鼓室型 & $12 耳$ \\
上鼓窒型+後上部緊張部型 & $3 耳$ \\
後上部緊張部型 & $2 耳$ \\
病着型 & $3 耳$
\end{tabular}

表 2 術前の気導聴力, 骨導聴力ならびに気骨導差

\begin{tabular}{|c|c|c|c|c|c|}
\hline \multirow[b]{2}{*}{$(\mathrm{dB})$} & \multicolumn{2}{|c|}{ 気導聴力 (耳) } & \multicolumn{2}{|c|}{ 骨導聴力 (耳) } & \multirow{2}{*}{$\begin{array}{c}\text { 気骨尊差 } \\
\text { (耳) }\end{array}$} \\
\hline & 4分法 & $4 \mathrm{kHz}$ & 4分法 & $4 \mathrm{kHz}$ & \\
\hline $0 \sim 10$ & 0 & 0 & 8 & 4 & \\
\hline$\sim 20$ & 0 & 0 & 7 & 4 & \\
\hline$\sim 30$ & 1 & 2 & 3 & 3 & \\
\hline$\sim 40$ & 4 & 2 & 1 & 3 & \\
\hline$\sim 50$ & 12 & 4 & 0 & 4 & \\
\hline$\sim 60$ & 1 & 7 & 1 & 0 & \\
\hline$\sim 70$ & 1 & 2 & 0 & 2 & \\
\hline$\sim 80$ & 0 & 1 & 0 & 0 & \\
\hline$\sim 90$ & 0 & 0 & 0 & 0 & \\
\hline$\sim 100$ & 0 & 1 & 0 & 0 & \\
\hline$\sim 110$ & 1) & 1) & 0 & 이 & \\
\hline
\end{tabular}

表 3 自覚症状

\begin{tabular}{lr}
\hline \hline 耳漏 & 19 耳 \\
難聴 & 18 耳 \\
めまい & 12 耳 \\
耳鳴 & 7 耳 \\
顔面神経麻㾝 & 2 耳
\end{tabular}

刺激で誘発される瘦孔の存在を疑わせるめまいは 12 耳 （60\%)に認められたに留まった。また，耳鳴が 7 耳に， 顔面神経麻痺が 2 耳に認められた（表 3 )。瘦孔症状の陽 性率は低く，6耳 $(30 \%)$ に認められたのみであった。

\section{結 果}

瘦孔は全耳とも外側半規管に認められ， 1 耳は上半規 管にも認められた。瘦孔部病変の処理は原則として一期 手術で行うことをめざし, 真珠腫に対しては出来る限り 上皮の除去をはかり，肉芽性病変に対しては除去困難な ものは残した。 しかしながら，1耳関しては巨大㾇孔 のため真珠腫上皮を残さざるを得なかった。また，操作 時に外リンパ流出が認められた症例はなかった. 真珠腫 に対する我々の基本術式は外耳道再建・乳突腔充填型の 鼓室形成術であり12)，瘉着症以外は一期的な手術を行 っているが，これら瘦孔症例に対しては開放型の鼓室形 成術を行ったものも多く，8耳あった。術式別にみると， 20 耳中 18 耳に鼓室形成術が施行されたが，吕型変法が最 も多く 2 耳に対しては併せて顔面神経減圧術が行われた。 残る 2 耳に対しては, それぞれ中耳根治手術, 聴保根治 手術が行われた(表 4 ).

斎藤ら 1 2 $\mathrm{mm}$ を中, $1 \mathrm{~mm}$ 以下を小として, 瘦孔の大きさと 術前骨導聴力との関係について検討した. 大㾇孔例で会 話音域抒よび $4 \mathrm{kHz}$ の骨導聴力高度低下例が認められ たが，各㾇孔の大きさでばらつきが認められ，瘦孔の大 きさと聴力との間に明らかな相関関係は認められなかっ た（図 1 )。ささらに，瘦孔の大きさと術前のめまい，瘻孔

表 4 手術術式

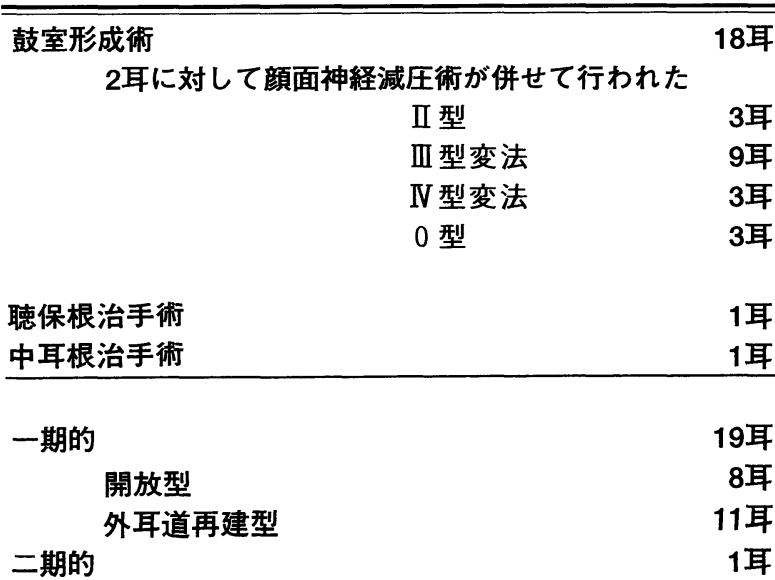



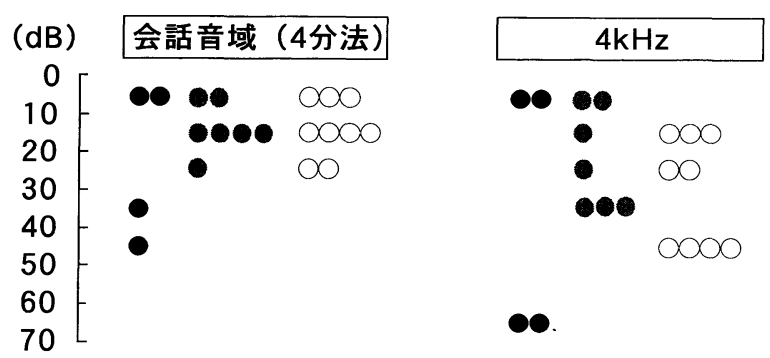

- 大 $(2 \mathrm{~mm}$ 以上 $)$ 中 $(1 \sim 2 \mathrm{~mm})$ 小 $(1 \mathrm{~mm}$ 以下 $)$

図 1 瘻孔の大きさと術前骨導值

症状の有無との関係について検討したが, 各大きさの瘻 孔群間で症状の出現頻度に大差なく, 相関関係は認めら れなかった（図 2-a, b).

予後に関しては，少なくとも 1 年の経過観察を行い，
めまい

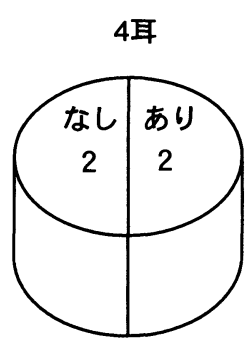

大瘦孔
7 耳

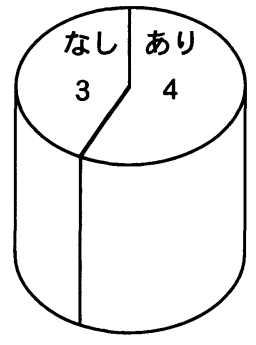

中瘦孔

a

瘦孔症状

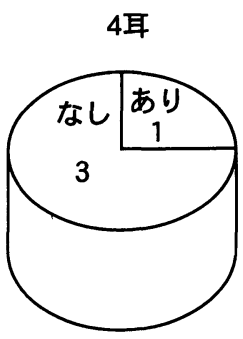

大湲孔

7耳

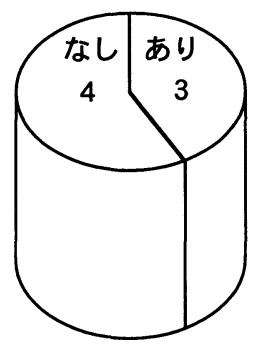

中瘦孔

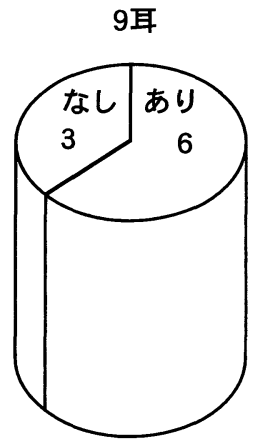

小瘦孔

9耳

b

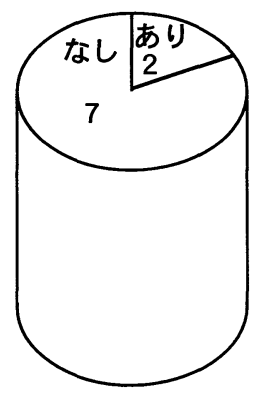

小瘦孔
全例めまいが消失あるいは軽快し耳漏も停止している. また，最終外来受診時の聴力を用いて，骨導聴力の術前 後の変化を検討したが，真珠腫上皮を残した 1 耳で術後 $4 \mathrm{kHz}$ の著しい低下を認めたものの骨導聴力の大きな変 化は認めず, 会話音域 4 分法平均聴力で術前 $15.3 \pm 12.0$ $\mathrm{dB}$ が術後 $16.4 \pm 14.4 \mathrm{~dB}$ となった. 内耳に対する侵襲 をよく反映すると思われる $4 \mathrm{kHz}$ です術前 $26.5 \pm 18.6$ $\mathrm{dB}$ から術後 $30.0 \pm 22.9 \mathrm{~dB}$ といら変化に留まった(図 3 ).

(dB)

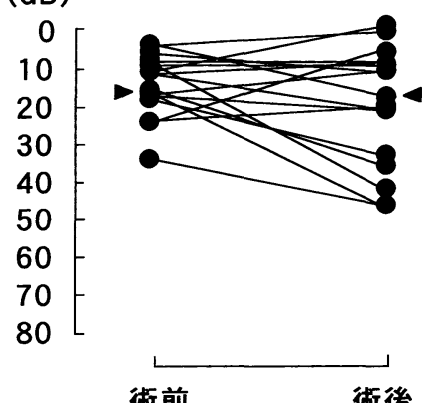

術前

術後

術前

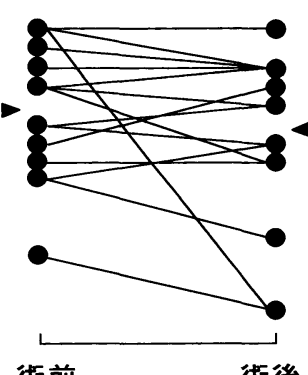

術後

図 3 術前・術後の骨導聴力 $(\boldsymbol{\Delta}$ 印は各平均値を示す.)

考察

慢性中耳炎の手術に際して迷路瘦孔に遭遇する頻度に ついては，従来多くの報告があり，3.6～ $8.2 \%$ と報告さ れている3 ${ }^{3)}$. 対象を真珠腫性中耳炎に限ると 4.8 $13.9 \%$ と報告され ${ }^{9) \sim 21)}$, 欧米における多数例での報告 では $10 \%$ 前後の頻度とされ, 真珠腫性中耳炎手術に扣い 
ては常に瘦孔の存在を念頭において手術を行らべきであ ると主張する術者が多い。

わが国においても同様の頻度が報告されているが，肉 芽性中耳炎に拈ける合併子稀ではなく, 特に再手術例で の瘦孔合併が多いことが指摘されている3778).

瘦孔の発生部位については外側半規管が最も多く, 瘦

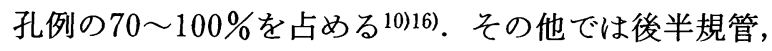
前半規管にも瘦孔を合併する例や前庭, 蝸牛をで侵襲す る広範な大㾇孔なども報告されている。

瘦孔例の診断に関しては，これまでめまいや瘦孔症状 が大きな手掛かりとされ，これらの症状と瘦孔との相関 が諸家によって検討されてきた. めまいや平衡障害は瘦 孔例の大多数で認められると報告されてきたが，逆にめ まいや平衡障害のない症例で瘦孔が存在する症例も少な くない，瘦孔症状の陽性率については40～60\%とする報 告が多く10141415)1819)，最も高い陽性率を報告している McCabe $^{16)}$ でも $72 \%$ で, 瘦孔症状の陽性率は決して高く ない，従って，これらの臨床症状や所見から瘦孔の合併 を診断することは必ずしも容易でない，ただ，近年画像 診断が著しく進歩し, 側頭骨高分解能 CT P MRI によ り, 骨の破壊, 吸収や真珠腫病変, 内耳リン八腔の描出 が可能となり, 迷路瘦孔の有無や部位, 大きさなどを比 較的容易に診断できるようになった ${ }^{21)}$. 本症例群におい ても, 全例, 術前 CT で瘦孔存在の可能性を指摘し得た.

今回の我々の観察では, 慢性中耳炎手術例384耳中迷 路瘦孔は20耳 $(5.2 \%)$ 飞認められたが, 全例真珠腫性中 耳炎例に合併しており, 真珠腫性中耳炎中の迷路瘦孔の 合併頻度は $13.2 \%$ であった. 瘦孔部位は全例外側半規管

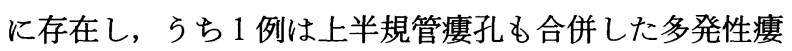
孔であった．この頻度は従来の欧米および本邦での報 告3) 20) と類似した.

瘦孔の大きさと術前聴力の関係をみると, 長径 $2 \mathrm{~mm}$ 以上の大瘦孔例で会話音域怙よび $4 \mathrm{kHz}$ で骨導聴力の 低下を認めたものもあったが, 全症例で蝸牛機能は残存 しており, 瘦孔の大きさと術前骨導聴力との間には個々 の症例差が大きく, 明らかな相関関係は認められなかっ た. これらの観察結果から, 外側半規管瘦孔は卵円空, 岬角部の㾇孔にくらべて内耳の聴覚機能を障害する可能 性が低いと推測された。

めまい，平衡障害などの自覚的めまいを訴えたものは 20 耳中 12 耳 $(60 \%)$ であったが, 瘦孔症状の陽性率は 20 耳 中 6 耳 $(30 \%)$ と低率であった。これらの前庭症状と瘦孔
の大きさの関係をみたが症例によって一定せず相関関係 は認められなかった. 瘦孔症状の出現には瘦孔テストで の圧刺激が瘦孔部へ確実に加わる必要があり, 検查方法, 病変の状態によって修飾され, そのため瘻孔テストでの 低い陽性率と低い相関を認めたものと推測された。

迷路瘦孔に対する手術法拈よび瘦孔処理に関しては古 くから多くの議論がなされてきた．1960年代までは多く の耳科医は迷路瘦孔の処理は直ちに不可逆性内耳炎に進 展するとして，その処理には極めて消極的であった。 1970年代に入り, 外耳道保存型あるいは乳突腔充媜型鼓 室形成術が発展し，外側半規管に存在する瘦孔に対して 積極的に瘦孔上の真珠腫上皮を除去する方法が行われる ようになり，蝸牛機能の低下を起こさないで瘦孔処理が 行えることが一般に知られるようになった。

Ritter ${ }^{4)}$ は50例の瘦孔症例を報告し, 瘦孔上の真珠腫 上皮を除去した例では残存させた例にくらべて高率に内 耳機能を障害する危険性が高いとして瘦孔上上皮は残存 させるのがよいと結論した. 一方, Palva ら5) は30例の 瘦孔症例の治療経験から，除去例中 2 例に術後に壟を招 来したが, 全例乾燥耳となり, 一方, 残存例では術直後 に感音性難聴を招来したものはなかったが，かなりの例 で耳漏が残り，術後経過観察中に内耳機能低下をきたし たとして結論的には瘦孔上上皮は除去した方がよいと述 べた。

以後多くの術者が多数例の経験を報告し, 瘦孔上病変 の除去か残存かについて多くの論争が行われたが，米国 ではSheehy ら 13114) が， ヨーロッパではSanna ら 17)20) が，それぞれ症例を重ねながら術式の改善を加え，現在 では外側半規管㾇孔に対しては, (1)長径 $2 \mathrm{~mm}$ 以下の中 -小㾇孔では閉鎖術式で対処し, 㾇孔上病変は除去する,

(2)長径 $2 \mathrm{~mm}$ 以上の大瘦孔では一次手術では瘦孔上病変 を残し，二次手術で除去する，(3)乳突開放術式では瘦孔 上病変を残す, (4)多発性ない儿進展型瘦孔括よび蝸牛瘻 孔では病変を除去しても残しても最終的に聴力を保存す ることは極めて難しい，(5)瘦孔の閉鎖には軟部組織のみ でなく，軟骨・骨などの硬組織も併用するのが望ましい， などの一般的合意が得られているようである.

我々は1990年までは瘦孔症例に対して中耳根治手術, 聴保根治手術を含む乳突腔開放術式でできるだけ瘦孔上 病变を除去する方法を用いてきた．1990年後半からは真 珠腫症例に対して外耳道再建, 乳突腔充填型鼓室形成術 を行うようになり122)，外側半規管瘻孔に対して積極的 
に癭孔上病変を除去する術式を行ってきた。そして，瘦 孔閉鎖は筋膜被覆で対処してきた．真珠腫が錐体尖へ侵 入し，多発性㾇孔をきたした 1 耳を除き，この術式で瘦 孔症例に対処してきたが，19耳全耳(1 耳は二期手術で 瘦孔上病变を除去)で注涪術前骨導聴力を保存でき, 術 後高度感音性難聴を招来したものはなかった。これら19 耳は術後 1 年以上の経過観察で全耳乾燥状態を維持し, めむいの消失を認めた。

以上の文献的考察および自験例の観察から迷路㾇孔が 外側半規管に限局している限り, 瘦孔上病変は積極的に 除去するのがよいと考光る．ただし，大瘦孔では二期手 術で除去する方がょり安全であろう。また，大瘦孔を除 き，その閉鎖には筋膜などの軟部組織のみの被覆で十分 と考光ている.

\section{まとめ}

過去 5 年間に経験した迷路㾇孔症例 20 耳の臨床観察を 行い, 次の結果を得た.

1) 迷路瘦孔は慢性中耳炎手術症例の $5.2 \%(20$ 耳 $/ 384$ 耳)に認められた．全例真珠腫性中耳炎に合併しており， 真珠腫性中耳炎の $13.2 \%$ に認められた。

2 ) 瘦孔の部位は, 外側半規管19耳, 多発性瘻孔(上 および外側半規管) 1 耳であった。

3 ）術前骨導閾值は会話音域で $15.3 \pm 12.0 \mathrm{~dB} ， 4$ $\mathrm{kHz}$ で $26.5 \pm 18.6 \mathrm{~dB}$ であった．自覚的めまいは全症 例の $60 \%$ に，瘦孔症状は $30 \%$ に認められ，いずれも低率 であった.

4 ) 外側半規管瘦孔 19 耳で瘦孔上病変は除去されたが, 全例で骨導聴力は保存された。

以上の結果から真珠腫性中耳炎に打ける外側半規管瘻 孔に対しては瘦孔上病変を積極的に除去するのがよいと 考えられた。

なお，本論文の要旨は第 95 回日本耳鼻咽喉科学会総会(平成 6 年 5 月19 21日，新潟市)に执いて口演した。

\section{参考文献}

1) Saito R, Hatano A, Uno Y, et al : Results of canal reconstruction tympanoplasty (CRT) in cholesteatoma. Proceedings of the Fourth International Conference on Cholesteatoma and Mastoid Surgery (ed by Nakano Y). pp 683 686, Kugler publications, Amsterdam/New York, 1992.
2 ) 前田 学, 斉藤龍介, 宇野芳史, 他: 真珠腫性中耳炎に対 する外耳道再建 - 乳突腔充填型㪗室形成術. Otol Jpn 4 : 403, 1994.

3 ）斎藤春雄, 村田清高, 岸本誠司, 他 : 迷路瘦孔之術後聴力. 耳鼻臨床 $72: 3 \sim 7,1979$.

4) Ritter FN : Chronic suppurative otitis media and the pathologic labyrinthine fistula. Laryngoscope 80 : 1025 1035, 1970.

5 ) Palva T, Kärjä J and Palva A : Opening of the labyrinth during chronic ear surgery. Arch Otolaryngol $93: 75 \sim 78$, 1971.

6) Abramson M, Harker LA and McCabe BF : Labyrinthine fistula complicating chronic suppurative otitis media. Arch Otolaryngol $100: 141 \sim 142,1974$.

7 ）斉藤龍介，小出郁夫，上田節夫，他：慢性中耳炎に和ける 迷路瘦孔に関する臨床的観察. 臨床耳科 $13: 48 \sim 49,1986$.

8 ）佐伯忠彦, 暁 清文, 柳原尚明：迷路炎 - 迷路庫孔一手 術例の検討から一. Equilibrium Res $47: 328 \sim 332,1988$.

9 ) Gacek RR: The surgical management of labyrinthine fistula in chronic otitis media with cholesteatoma. Ann Otol Rhinol Laryngol Suppl $10: 1 \sim 19,1974$.

10) Tos $M:$ Treatment of labyrinthine fistulae by a closed technique. ORL $37: 41 \sim 47,1975$.

11) Law KP, Smyth GDL and Kerr AG : Fistulae of the labyrinth treated by staged combined approach tympanoplasty. J Laryngol Otol 89 : 471 478, 1975.

12) Wayoff MR and Friot JM : Analysis of one hundred cases of fistulas of the external semicircular canal. Cholesteatoma ; first international conference (ed by McCabe BF, Sadé J and Abramson M). pp 463 464, Aesculapius Publishing Co, Birmingham, Ala., 1977.

13) Sheehy JL : Management of labyrinthine fistula. Clin Otolaryngol $3:$ :405 414, 1978.

14) Sheehy JL and Brackmann DE : Cholesteatoma surgery; management of the labyrinthine fistula $-\mathrm{a}$ report of 97 cases. Laryngoscope $89: 78 \sim 87,1979$.

15) Pfaltz CR : Complication of otitis media. ORL $44: 301 \sim$ 309, 1982.

16) McCabe BF : Labyrinthine fistula in chronic mastoiditis. Ann Otol Rhinol Laryngol Suppl 112 : 138 141, 1983.

17) Sanna M, Zini C, Bacciu S, et al : Management of the labyrinthine fistula in cholesteatoma surgery. ORL 46 : 165 172, 1984.

18) Gormley PK : Surgical management of labyrinthine fistula with cholesteatoma. J Laryngol Otol $100: 1115 \sim 1123$, 1986.

19) Ostri B and Bak-Pedersen $K$ : Surgical management of labyrinthine fistulae in chronic otitis media with cho- 
lesteatoma by a one-stage closed technique. ORL $51: 295$ $\sim 299,1989$.

20) Sanna M, Zini C, Bacciu S, et al : Management of labyrinthine fistula. Proceedings of the Fourth International Conference on Cholesteatoma and Mastoid Surgery (ed by Nakano Y). pp 557 558, Kugler publications, Amsterdam/New York, 1992.
21）飯野ゆき子, 中村 寧, 平川治男, 他 : 真珠腫による内耳 瘻孔症例の術後聴力. 耳鼻臨床 $88: 31 \sim 36,1995$.

$$
\left.\begin{array}{l}
\text { 原稿受付 : 平成 } 7 \text { 年 } 10 \text { 月 } 9 \text { 日 } \\
\text { 原稿採択 : 平成 } 7 \text { 年 } 12 \text { 月 } 3 \text { 日 } \\
\text { 別刷請求先 : 前田 学 } \\
\text { 干 } 700 \text { 岡山市伊福町 } 1-17-18 \\
\text { 岡山済生会総合病院耳鼻咽喉科 }
\end{array}\right)
$$

